\title{
Real-world emissions of gasoline passenger cars in Macao and their correlation with driving conditions
}

\author{
Z. Wang $\cdot$ Y. Wu $\cdot$ Y. Zhou $\cdot$ Z. Li $\cdot$ \\ Y. Wang $\cdot$ S. Zhang • J. Hao
}

Received: 26 April 2012/Revised: 7 March 2013/Accepted: 16 March 2013/Published online: 17 April 2013

(C) Islamic Azad University (IAU) 2013

\begin{abstract}
Using a portable emissions measurement system, 16 gasoline passenger cars were tested on a fixed route consisting of different types of roads in Macao and the data were normalized with the vehicle-specific power bin method. The normalized $\mathrm{HC}, \mathrm{CO}$ and $\mathrm{NO}_{X}$ emission levels of the seven passenger car samples with model year older than 2000 were $3.19 \pm 5.04, \quad 14.59 \pm 22.88,2.57 \pm$ $2.12 \mathrm{~g} / \mathrm{km}$, respectively. The $\mathrm{HC}, \mathrm{CO}$ and $\mathrm{NO}_{X}$ emission levels of other newer samples were $0.02 \pm 0.02$, $0.23 \pm 0.29$ and $0.10 \pm 0.13 \mathrm{~g} / \mathrm{km}$, respectively. The scrappage of old passenger cars in Macao should be a high priority to control the total emissions of motor vehicles. Based on relative emission levels, a clear and similar pattern for gaseous pollutants and fuel consumption with driving conditions was identified. The emissions of $\mathrm{HC}$, $\mathrm{CO}$ and $\mathrm{NO}_{X}$ are best fitted to average speed with inverse functions. Fuel consumption is best fitted to average speed with a power function. Compared to the average driving conditions, the emission factors of $\mathrm{HC}, \mathrm{CO}$ and $\mathrm{NO}_{X}$ and fuel consumption of gasoline passenger cars during the rush hours on the Macau Peninsula will be increased by 61, 55,45 and $90 \%$, respectively. This situation will deteriorate by 2015 if no further transportation management strategies are implemented in Macao. To save energy and mitigate the air pollutant emissions in the urban area,
\end{abstract}

Z. Wang · Y. Wang

Faculty of Science and Technology, University of

Macao, Macao SAR, China

Y. Wu $(\bowtie) \cdot$ Y. Zhou $\cdot$ Z. Li · S. Zhang $\cdot$ J. Hao School of Environment, and State Key Joint Laboratory of Environment Simulation and Pollution Control, Tsinghua University, 100084 Beijing, China

e-mail: ywu@tsinghua.edu.cn improved traffic planning and travel demand management are also necessary.

Keywords Portable emissions measurement system (PEMS) · Emission · Gasoline passenger cars · Driving conditions

\section{Introduction}

The rapid growth of the vehicle population in China raises a substantial concern for its adverse impacts on urban air quality and human health. Vehicle emissions will not only contribute to higher roadside pollutant concentration but also degrade ambient air quality (Kho et al. 2007). According to the atmospheric emission census carried out by the Ministry of Environmental Protection (MEP) of China (2010), on-road motor vehicles contributed $31 \%$ of the $\mathrm{NO}_{X}$ emissions in China in 2007. Among the vehicle fleet, the gasoline vehicle is the largest source of both $\mathrm{CO}$ and $\mathrm{HC}$ emissions. More than $70 \%$ of the vehicular $\mathrm{CO}$ and $\mathrm{HC}$ emissions in 2010 came from gasoline vehicles (MEP China 2011).

Macao is composed of the Macao Peninsula, Taipa Island and Coloane Island. It has an area of $29.7 \mathrm{~km}^{2}$ and a population of 560,100. By 2011, the total vehicle population in Macao reached 206,349 with an ownership rate of about 368 vehicles per 1,000 persons. Light-duty vehicles and motorcycles account for about $97 \%$ of the total vehicle population (Macao Statistics and Census Service 2012). Motor vehicle emissions are considered to be the dominant local source of air pollutants in Macao since the region is not directly influenced by other local industrial emissions (Hao et al. 2000; Wu et al. 2002). Furthermore, the interaction of the local wind field and surrounding 
building geometry in the central business district results in a "street canyon" effect that will extend the residence time of pollutants (Chan et al. 2001), so the accumulation of local air pollution may be amplified (Malakootian and Yaghmaeian 2004; Tang and Wang 2007). $\mathrm{O}_{3}$, considered a key secondary air pollutant formed by the presence of $\mathrm{NO}_{X}$ and $\mathrm{HC}$ mostly from vehicular emissions, has a relatively high concentration on Taipa Island. According to the updated 2005 WHO air quality guidelines, the $\mathrm{O}_{3}$ concentrations at the two monitoring stations located in Taipa Island exceeded the 8 -h average $\mathrm{O}_{3}$ threshold $\left(100 \mu \mathrm{g} / \mathrm{m}^{3}\right)$ over $10 \%$ of the time in 2009-2010.

There have been several studies to assess the emission profiles and impacts of more stringent emission control policies and regulations for the gasoline passenger cars in China (Hao et al. 2001; Wu et al. 2011; Yang et al. 2011). On-road emission measurements have become very important as they can provide real-world emission status of in-use vehicles. There are several on-road emission measurement methods including chasing car measurement (Tang and Wang 2006; Westerdahl et al. 2009), remote sensing and on-board measurement. With the recent development of portable emissions measurement system (PEMS), researchers around the world have measured the on-board emission characteristics of motor vehicles under real-world driving conditions. Unal et al. (2004) analyzed the effect of different driving conditions on in-use emission characteristics with an on-board emission testing system. Poppel and Lenaers (2005) have used on-road tests to study the emission benefits of diesel buses retrofitted with continuous regeneration traps (CRT). In China, Tsinghua University (Hu et al. 2004; Yao et al. 2007; Li et al. 2009) has measured the emission characteristics of gasoline passenger cars and heavy-duty diesel trucks under realworld driving conditions in various cities. The results have already been applied to improve the reliability of emission models and evaluate the benefits of transportation control measures in Beijing during the 2008 Olympics (Zhou et al. 2010). The Shanghai Academy of Environmental Sciences (Chen et al. 2007) analyzed the effect of driving conditions on real-world emission characteristics of the heavy-duty diesel vehicles in Shanghai using PEMS. The Chinese Research Academy of Environmental Sciences ( $\mathrm{Li}$ et al. 2009; Hu et al. 2012) analyzed the future emission control strategies based on the real-world emission characteristics of diesel trucks and taxis measured by PEMS. Portable emission measurement technologies have provided useful tools for the better understanding of the real-world vehicle emissions and decision making for in-use vehicle emission control strategies.

In this study, we investigate the on-road exhaust emissions of gasoline passenger cars in Macao with PEMS. The emission tests were carried out in Macao from 30 April
2010 to 6 May 2010. The impacts of vehicle model year and vehicle mileage to the on-road emissions of gasoline cars are evaluated. A method is also developed to analyze the effect of driving conditions on vehicle emission characteristics of Macao. This study aims to help policy-makers better understand the real emission profiles of gasoline passenger cars and promote development plans for systematic control of light-duty gasoline vehicles (LDGVs) in Macao's future automarket and current in-use fleet.

\section{Materials and methods}

On-board emissions measurement system

The SEMTECH-DS (Sensor's Inc.) on-board emissions measurement system was used to measure the on-road second-by-second emissions of 16 light-duty passenger cars. It has a non-dispersive infrared analysis (NDIR) unit to measure $\mathrm{CO}$ and $\mathrm{CO}_{2}$ concentrations, a heated flame ion detector (HFID) to measure total hydrocarbons (THC) concentration, and a non-dispersive ultraviolet (NDUV) unit to measure $\mathrm{NO}$ and $\mathrm{NO}_{2}$ concentrations simultaneously. $\mathrm{O}_{2}$ concentration was measured by an electrochemistry method. The exhaust flow rate from the vehicle tailpipe was recorded by the SEMTECH-EFM mass flow measurement device so the fuel consumption and mass emissions of regulated pollutants could be calculated based on the pollutant concentration and exhaust mass flow rate. In addition, a GPS device was used to record vehicle speed as well as the vehicle's location information (longitude, latitude, and altitude). For quality assurance, zeroing and calibration was conducted for NDIR, HFID and NDUV units prior to testing each day during the campaign with standard zero and calibration gases. Second-by-second data of pollutant concentration, exhaust flow rate, vehicle speed, ambient temperature and humidity were obtained during the on-road emissions test.

Vehicle samples

According to the database of the whole passenger car fleet provided by the Macao Transportation Affairs Agency, 16 gasoline passenger cars were selected for on-road testing. These 16 vehicle samples covered various model years and mileages, and could be considered as representative of the whole private car fleet. Table 1 summarizes the information for these vehicles including the manufacturer, model, mileage, model year, and engine displacement. The passenger cars were numbered according to the order of their model years. The engine displacement of most samples is from 1.3 to $1.8 \mathrm{~L}$, which is the most common displacement range of private passenger cars in Macao. It should be 
Table 1 Information of the gasoline passenger cars selected for the emission tests

\begin{tabular}{|c|c|c|c|c|c|c|}
\hline Vehicle No. & Manufacturer & Model & Model year & Odometer (km) & GVW (kg) & $\begin{array}{l}\text { Engine } \\
\text { displacement (L) }\end{array}$ \\
\hline 1 & Mitsubishi & Lancer GLXi & 1991 & 159,707 & N/A & 1.5 \\
\hline 2 & Daihatsu & Cuore & 1992 & 66,713 & N/A & 0.9 \\
\hline 3 & Daihatsu & Charade CX & 1994 & 69,671 & 1,350 & 1.3 \\
\hline 4 & Toyota & Corolla XLi & 1996 & 107,113 & 1,465 & 1.3 \\
\hline 5 & Ford & Festiva 1.3 GLI & 1997 & 86,437 & 1,349 & 1.3 \\
\hline 6 & Toyota & Corolla Gli & 1997 & 76,350 & 1,515 & 1.5 \\
\hline 7 & Mazda & New 323 GLI5 & 1998 & 103,651 & 1,565 & 1.5 \\
\hline 8 & Toyota & Camry & 2002 & 36,989 & 1,935 & 2.4 \\
\hline 9 & Toyota & Echo Verso & 2002 & 57,403 & 1,530 & 1.3 \\
\hline 10 & Toyota & Echo Verso & 2002 & 52,904 & 1,530 & 1.3 \\
\hline 11 & Toyota & Corolla 1.5 GL-I & 2004 & 75,008 & 1,555 & 1.5 \\
\hline 12 & Toyota & Corolla 1.5 GL-i & 2004 & 71,884 & 1,555 & 1.5 \\
\hline 13 & Toyota & Voxy Z & 2006 & 69,900 & 1,920 & 2.0 \\
\hline 14 & Honda & Civic & 2006 & 15,443 & 1,680 & 1.8 \\
\hline 15 & Suzuki & Swift 1.3 & 2006 & 26,694 & 1,470 & 1.3 \\
\hline 16 & Honda & Civic 1.8 VTI & 2007 & 78,764 & 1,680 & 1.8 \\
\hline
\end{tabular}

$G V W$ gross vehicle weight, N/A not available

noted that the majority of the sampled cars were made in Japan, which is attributed to the fact that $80 \%$ of the LDGVs in Macao are imported from Japan. Macao has implemented its first emission standard for new motor vehicles with more than 3 wheels in 2012. Before then, the gasoline passenger car samples could not be classified by sets of emission standards. But, in general, the vehicles should meet the emission standards of the country of production for their respective model years.

\section{Test route}

The on-road emission tests were carried out in Macao in the daytime from 30 April 2010 to 6 May 2010. The test route for real-world vehicle emissions measurement is shown in Fig. 1, with a total length of about $28 \mathrm{~km}$ and duration of about $1 \mathrm{~h}$. The differences in driving conditions between different road sections are also shown in Fig. 2 . The route covers several road types with different traffic flows, including the local streets/roads and two bridges that connect the Macao Peninsula and Taipa Island. Given the traffic infrastructure, there is no typical high-speed freeway in Macao. Thus, the maximum vehicle speed during all of the tests was below $80 \mathrm{~km} / \mathrm{h}$. The driving conditions varied significantly on different road sections during the tests. Road sections No. 1 and 3 include the two bridges and represent the urban 'expressway' without stops as the vehicle speed on these two sections is generally higher than other sections. Road sections No. 2, 4 and 6 represent the city roads with light traffic congestion in Taipa Island and the newly developed area of Macao Peninsula. Road section No. 5, which crosses the downtown area of Macao Peninsula, is typical of local streets with heavy traffic flow.

Data processing

Although all of the 16 passenger cars were tested along the same route, the average speed of each car is slightly different due to unpredictable changes in the real-world traffic conditions. The average vehicle speed ranges from 28.0 to $40.5 \mathrm{~km} / \mathrm{h}$ for all tested vehicles with the average at $34.3 \mathrm{~km} / \mathrm{h}$. Since the distance-based emission factor is strongly related to the vehicle speed, the emissions data for these 16 gasoline passenger cars were normalized to the same average speed using the vehicle-specific power (VSP)-bin method before comparison. VSP is defined as the instantaneous power demand on the engine per unit vehicle mass which can be calculated by the vehicle speed, acceleration and other parameters. In this study, we applied the equation from the MOVES model developed by US Environmental Protection Agency (Koupal et al. 2004) for VSP calculation of all samples.

VSP can represent the driving conditions in an integrated way and show better correlations with emission rates of pollutants than other operating parameters. We established 22 operating mode bins defined by VSP and vehicle speed (see Table 2) to normalize the fuel consumption and emission factors based on the averaged driving cycle profile of the on-road tests conducted in Macao. These bins were slightly modified from the MOVES methodology due to the 
availability of test data in each bin, specifically in the highspeed segments. The distributions of operating mode of the averaged driving profile are shown in Fig. 3.

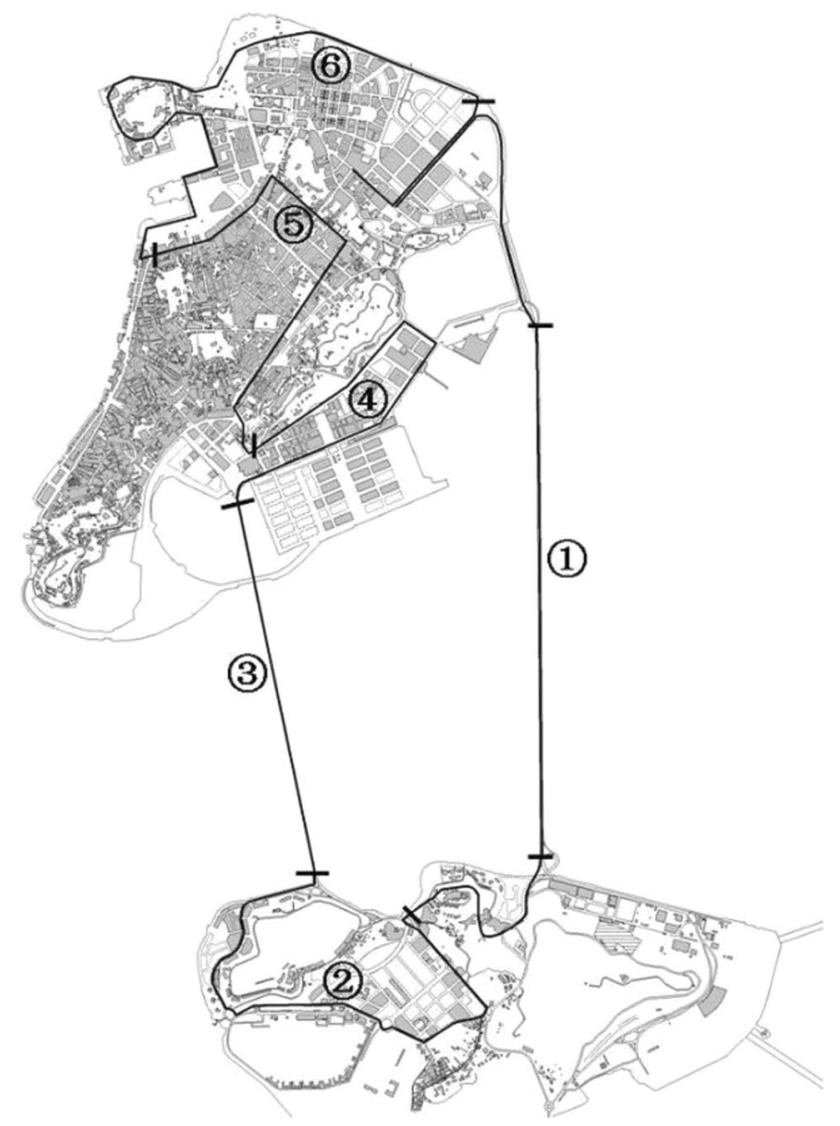

Fig. 1 The map of the on-road test route
The second-by-second emission rates (in $\mathrm{g} / \mathrm{s}$ ) for each individual passenger car were collected by PEMS. The distance-specific baseline emission factor in $\mathrm{g} / \mathrm{km}$ was further developed for each sampled car based on the average emission rates and time distribution of operating mode bins within the average driving cycle, as shown in Fig. 3.

$\mathrm{EF}_{0}=\frac{3,600 \sum_{i}\left(\overline{\mathrm{ER}_{i}} \times P_{i}\right)}{v_{0}}$

where $\mathrm{EF}_{0}$ is the baseline emission factor for a pollutant, $\mathrm{g} / \mathrm{km} ; \overline{\mathrm{ER}_{i}}$ is the average emission rate of pollutant $i$ for operating mode bin $i, \mathrm{~g} / \mathrm{s} ; P_{i}$ is the time percentage of operating mode bin $i$ in the average driving cycle; $v_{0}$ is the average speed of the average driving cycle, which is $34.3 \mathrm{~km} / \mathrm{h}$ in this study.

The fuel consumption of gasoline passenger cars was also calculated by the carbon balance method that is widely used for light-duty vehicles. In this study, the equation from the fuel economy standards for light-duty vehicles in China (AQSIQ China 2003) was used to calculate gasoline fuel consumption:

$$
\begin{aligned}
\mathrm{FC}= & \frac{0.1154}{D}\left[\left(0.866 \times \mathrm{EF}_{\mathrm{HC}}\right)+\left(0.429 \times \mathrm{EF}_{\mathrm{CO}}\right)\right. \\
& \left.+\left(0.273 \times \mathrm{EF}_{\mathrm{CO}_{2}}\right)\right]
\end{aligned}
$$

where $\mathrm{FC}(\mathrm{L} / 100 \mathrm{~km})$ is the gasoline consumption; $D(\mathrm{~kg} / \mathrm{L})$ is the density of gasoline, which was set to $0.767 \mathrm{~kg} / \mathrm{L}$ based on the gasoline fuel quality survey in Macao in $2011 ; \mathrm{EF}_{\mathrm{HC}}$ $(\mathrm{g} / \mathrm{km}), \mathrm{EF}_{\mathrm{CO}}(\mathrm{g} / \mathrm{km})$ and $\mathrm{EF}_{\mathrm{CO}_{2}}(\mathrm{~g} / \mathrm{km})$ are the emission factors of $\mathrm{HC}, \mathrm{CO}$ and $\mathrm{CO}_{2}$, respectively.
Fig. 2 The driving conditions on different road sections during an on-road emission test

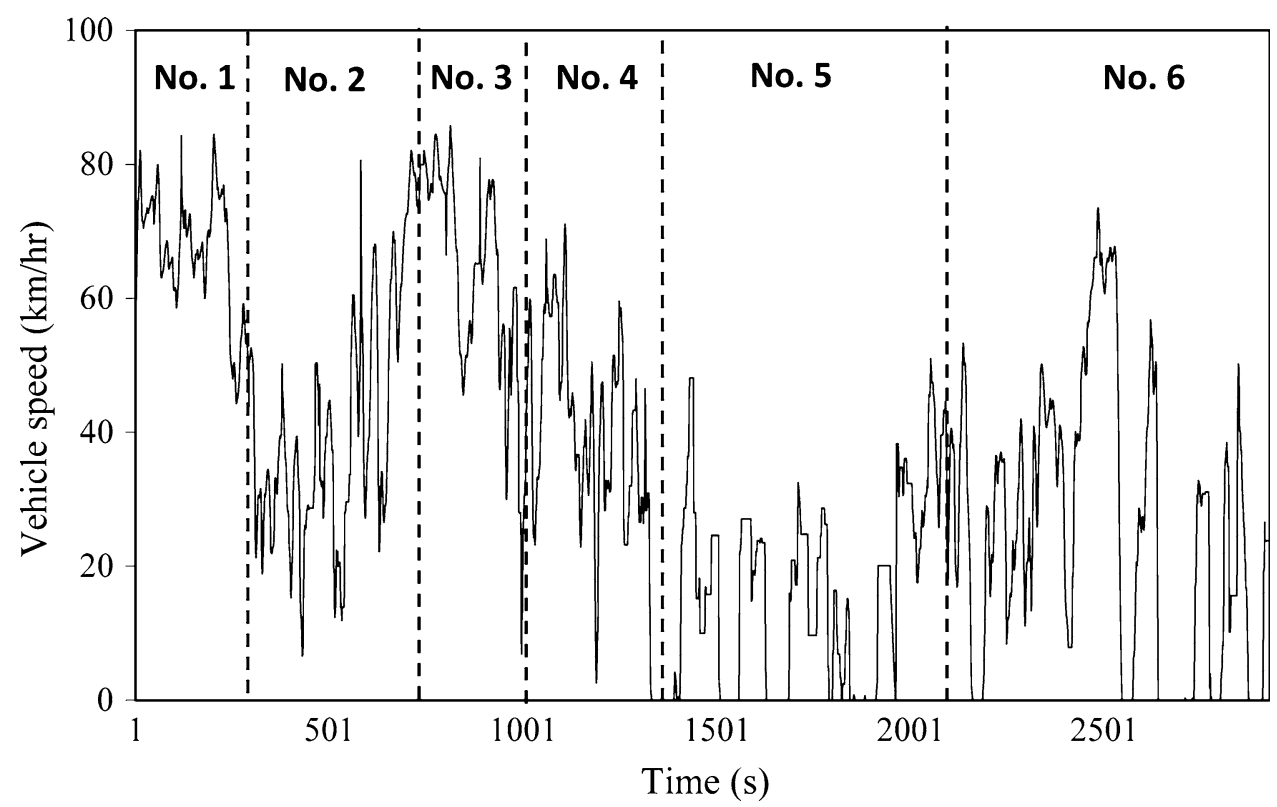


Table 2 Operating modes for emission binning

\begin{tabular}{|c|c|c|c|c|c|}
\hline \multirow[t]{2}{*}{ VSP (kW/ton) } & & \multicolumn{4}{|c|}{ Vehicle speed $(\mathrm{km} / \mathrm{h})$} \\
\hline & & $v<1.6$ & $1.6 \leq v<40$ & $40 \leq v<80$ & $v>80$ \\
\hline $\mathrm{VSP}<-4$ & \multirow{8}{*}{$\begin{array}{l}\text { Bin } 0 \\
\text { deceleration or braking }\end{array}$} & \multirow[t]{8}{*}{ Bin 1 idle } & Bin 11 & Bin 21 & \multirow[t]{5}{*}{$\operatorname{Bin} 35^{\mathrm{a}}$} \\
\hline$-4 \leq \mathrm{VSP}<-2$ & & & Bin 12 & Bin 22 & \\
\hline$-2 \leq \mathrm{VSP}<0$ & & & Bin 13 & Bin 23 & \\
\hline $0 \leq \mathrm{VSP}<2$ & & & Bin 14 & Bin 24 & \\
\hline $2 \leq \mathrm{VSP}<4$ & & & Bin 15 & Bin 25 & \\
\hline $4 \leq \mathrm{VSP}<6$ & & & Bin 16 & Bin 26 & Bin 36 \\
\hline $6 \leq \mathrm{VSP}<8$ & & & Bin 17 & Bin 27 & Bin 37 \\
\hline $\mathrm{VSP} \geq 8$ & & & Bin 18 & Bin 28 & Bin 38 \\
\hline
\end{tabular}

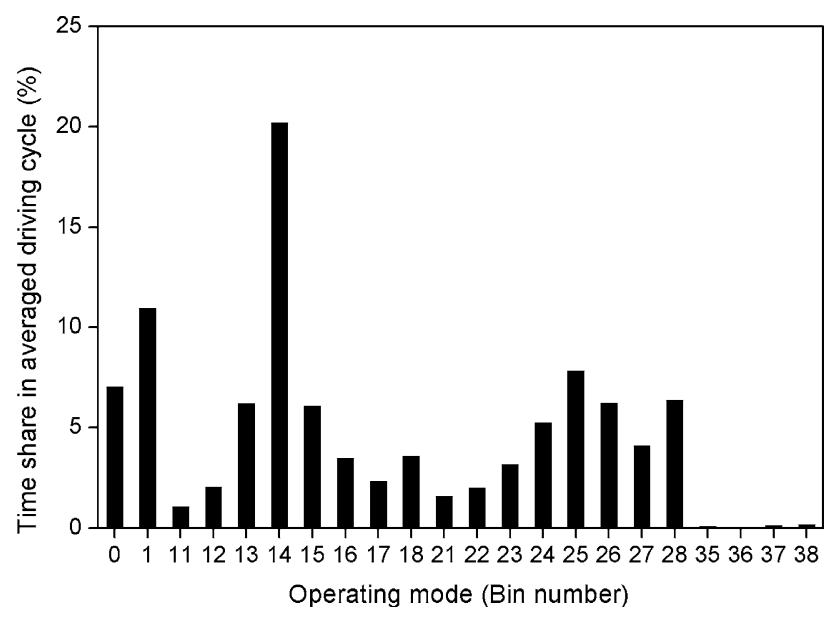

Fig. 3 Time share of the operating modes in the averaged driving cycle for all the passenger cars tested

To evaluate the effect of driving conditions on passenger car emissions, the dimensionless relative emission level is derived for each micro-trip between successive stops. The micro-trip has been widely used to develop driving cycles from real-world driving conditions (André 2004). The ratio of vehicle emissions of each micro-trip to the normalized emissions of specific vehicle sample calculated based on harmonized driving profiles is defined as the relative emission level, which mainly reflects the effect of driving conditions. By removing the impact of the baseline emission level of different vehicle samples, their relative emission level under micro-trips can be gathered for analyzing the effect of driving conditions. There are totally 194 valid micro-trips from all the tested passenger cars in this study. The process to calculate their relative emission level is summarized in the following equation.

$\mathrm{RE}=\frac{\mathrm{EM} / \text { Dist }}{\mathrm{EF}_{0}}$

where $R E$ is the dimensionless relative emission level of a micro-trip; $\mathrm{EF}_{0}(\mathrm{~g} / \mathrm{km})$ is the baseline emission factor of the tested vehicle sample; EM (g) is the total emissions during the micro-trip; Dist $(\mathrm{km})$ is the total length of the tested vehicle travelled in the micro-trip.

\section{Results and discussion}

Normalized emission factors

The normalized emission factors of the 16 gasoline passenger cars are shown in Fig. 4. As the vehicle samples were numbered by sequence of model year, it would usually be expected, and the data verify that the older, lower numbered cars generally have higher emissions than the higher numbered cars. Vehicles No. 1, 2, 3, 4 and 7 have much higher emission levels for all three pollutants than other vehicles. Their model years were 1991, 1992, 1994, 1996 and 1998, respectively. The vehicle model year 2000 is a clear cut line as significant emission change of gasoline passenger cars in Macao. Emission standards for gasoline passenger cars were tightened in 2000 in both the European Union (Euro III) and Japan (JLEV), which are the two largest sources of cars sold to Macao. As the passenger cars imported generally meet the standards of the source country, the in-use cars in Macao also showed clear change in emission control level for model year before and after 2000. However, vehicles No. 5 and 6 show much better emission performance than their counterparts registered before 2000. Their $\mathrm{NO}_{X}$ emissions are even close to the average of newer vehicle group. The emission of older vehicles can also be kept at a reasonable level with good maintenance. But currently Macao has no effective in-use emission inspection programs to identify them.

To better understand the effect of vehicle model year on the emissions of gasoline passenger cars in Macao, their emissions are compared in two groups. The first group consists of vehicles with model year older than 2000. The second group consists of vehicles with model year newer 
Fig. 4 Normalized on-road emission factors of the 16 gasoline passenger cars
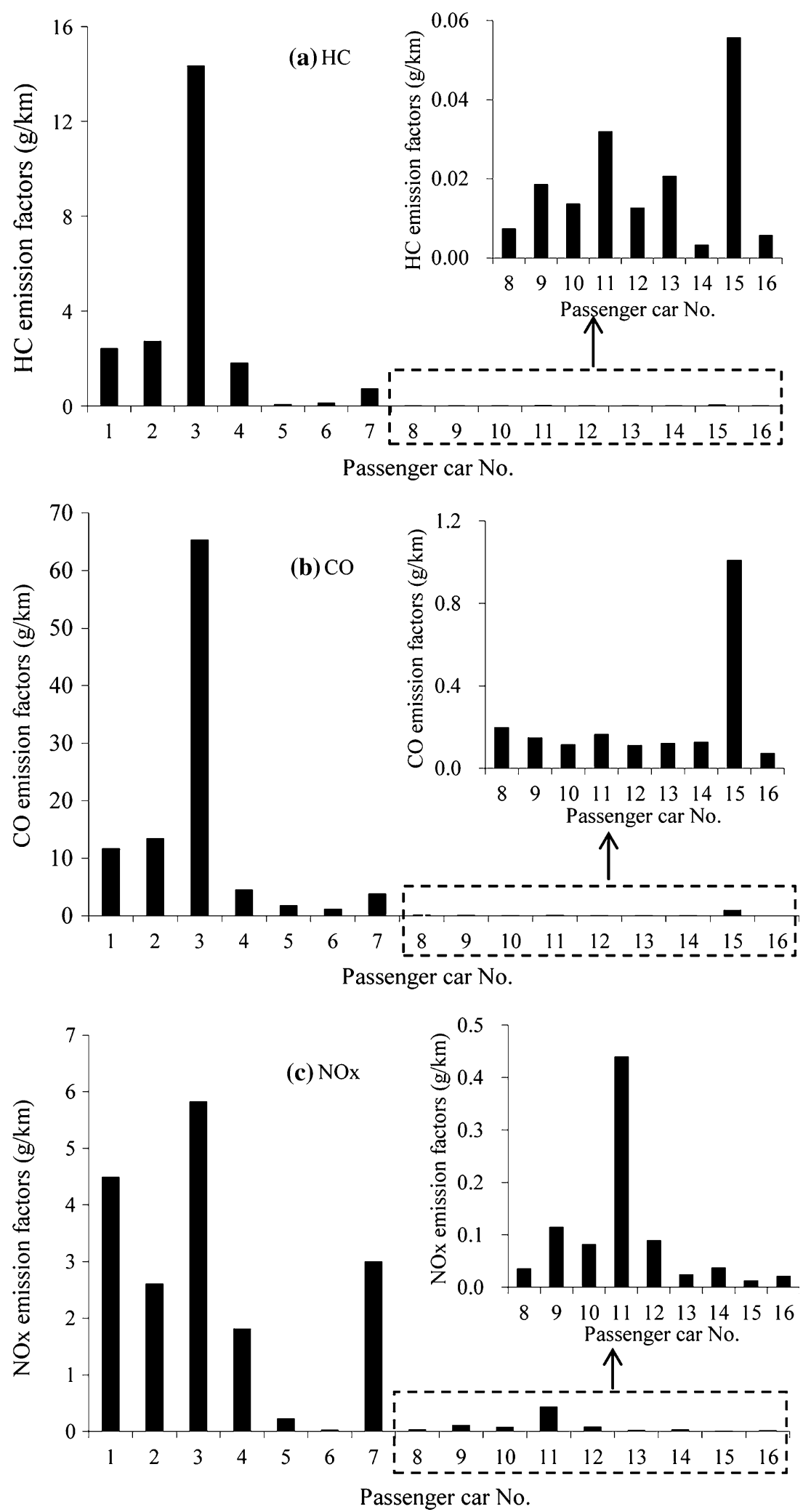
Table 3 Comparison of the emissions of gasoline passenger cars with diesel taxis in Macao and LDGVs in mainland China

\begin{tabular}{lccc}
\hline Vehicle group & \multicolumn{2}{l}{ Emission factors $(\mathrm{g} / \mathrm{km})$} & $\mathrm{CO}$ \\
\cline { 2 - 4 } & $\mathrm{HC}$ & & $\mathrm{NO}_{X}$ \\
\hline Gasoline passenger cars in Macao & & $14.59 \pm 22.88$ & $2.57 \pm 2.12$ \\
$\quad$ Older than 2000 & $3.19 \pm 5.04$ & $0.23 \pm 0.29$ & $0.10 \pm 0.13$ \\
Newer than 2000 & $0.02 \pm 0.02$ & $0.497 \pm 0.049$ & $0.572 \pm 0.040$ \\
Diesel taxis in Macao (Hu et al. 2012) & $0.046 \pm 0.005$ & & $1.9 \pm 1.1$ \\
LDGVS in mainland China (Huo et al. 2012) & & $33.4 \pm 21.7$ & $1.0 \pm 1.4$ \\
Euro 0 & $3.6 \pm 2.6$ & $11.3 \pm 10.6$ & $0.47 \pm 0.39$ \\
Euro I & $0.70 \pm 0.62$ & $2.2 \pm 2.3$ & $0.23 \pm 0.29$ \\
Euro II & $0.31 \pm 0.34$ & $0.40 \pm 0.21$ & $0.05 \pm 0.03$ \\
Euro III & $0.09 \pm 0.07$ & $0.02 \pm 0.01$ & \\
Euro IV & & & \\
\hline
\end{tabular}

than 2000. Table 3 compares the on-road emissions of gasoline passenger cars with diesel taxis in Macao $(\mathrm{Hu}$ et al. 2012) and LDGVs in mainland China (Huo et al. 2012). The model year of the taxi samples were between 2002 and 2009 except for one with the model year of 1998. Macao has more light-duty diesel passenger cars operating on the road than typical China cities. The comparison can also provide a very useful and important input to the decision making about the future fuel choice of passenger cars in China. The $\mathrm{HC}, \mathrm{CO}$ and $\mathrm{NO}_{X}$ emissions of gasoline passenger cars with model year newer than 2000 is 99,98 and $96 \%$ lower than those older samples, which indicates that the priority of light-duty vehicle emission control should be the scrappage of old vehicles. The emission levels of gasoline passenger cars newer than 2000 in Macao are close to Euro IV LDGVs in mainland China. The emission levels of $\mathrm{HC}$ and $\mathrm{NO}_{X}$ of passenger cars older than 2000 are close to Euro 0 LDGVs in mainland China, while their $\mathrm{CO}$ emission levels are close to Euro $1 \mathrm{LDGVs}$ in mainland China.

The $\mathrm{HC}, \mathrm{CO}$ and $\mathrm{NO}_{X}$ emissions of gasoline passenger cars with model year newer than 2000 are 57, 54 and $83 \%$ lower than diesel taxis with similar model year. The $\mathrm{NO}_{X}$ emissions of diesel taxis are nearly five times higher than that by their newer gasoline counterparts. In the next decade, control of $\mathrm{NO}_{X}$ emissions will be one of the top priorities for MEP. Light-duty gasoline vehicles are superior to the light-duty diesel vehicles in terms of $\mathrm{NO}_{X}$ control. However, for energy conservation and $\mathrm{CO}_{2}$ emissions mitigation, diesel engines have an inherent advantage.

To evaluate the effect of vehicle age on the emissions of newer models, we have sorted the emissions of vehicles imported and registered after 2000 based on the vehicle model year and accumulated mileage in Fig. 5 and Fig. 6, respectively. $\mathrm{HC}, \mathrm{CO}$ and $\mathrm{NO}_{X}$ emission factors of these gasoline passenger cars do not show significant deterioration with the accumulation of odometer distance up to $80,000 \mathrm{~km}$. The $\mathrm{CO}$ and $\mathrm{NO}_{X}$ emission factors reflect some deterioration with vehicle age, which may be attributed to the adoption of stricter emission standards in Japan and European Union. But there are two outliers each for $\mathrm{CO}$ and $\mathrm{NO}_{X}$ emissions, which are about four times higher than the average. The model years of $\mathrm{CO}$ and $\mathrm{NO}_{X}$ high emitters are 2004 and 2006, respectively. It indicates that it is necessary for Macao to adopt a strict in-use vehicle inspection program based on loaded exhaust measurement method and reasonable limits for vehicles with advanced control strategies. The program can help insure vehicle emission control systems operate properly. There are no routine emission inspection programs for in-use gasoline vehicles in Macao. An effective inspection and maintenance program with loaded testing methods and cut points for on-road vehicles will also help improve the emission status of in-use passenger cars in Macao.

Correlation between emissions of the gasoline passenger cars and driving conditions

Vehicle emissions change with on-road driving conditions. Average speed has been used as an important indicator of vehicle driving conditions for emission modeling in the COPERT model developed by the European Union (Gkatzoflias et al. 2007) and MOBILE model developed by the US Environment Protection Agency (US EPA 2001). Figure 7 presents the average emissions and fuel consumption of the nine passenger cars registered after 2000, with the average speed at six road sections. A similar pattern for fuel consumption as well as for the pollutant 

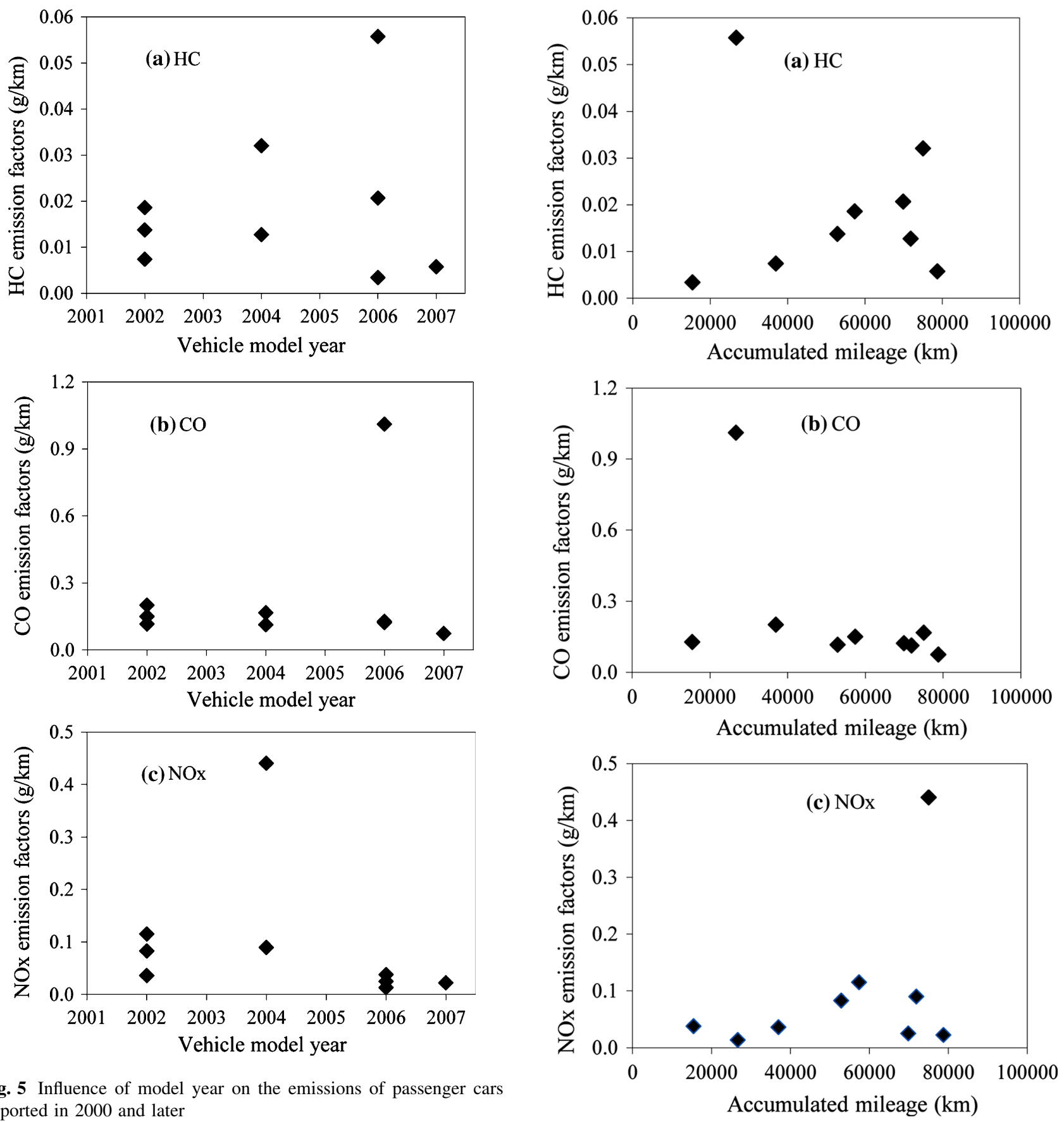

Fig. 5 Influence of model year on the emissions of passenger cars imported in 2000 and later

emissions with various road conditions could be identified. Road sections No. 1 and 3, which represent the city expressway, have the lowest fuel consumption among the six road sections. Road section No. 5, a typical case of local streets with heavy traffic flows, has the highest fuel consumption and emissions among the six road sections. The average fuel consumption of vehicles on road section No. 5 is $\sim 150 \%$ higher than that on road section No. 1 . The emission factor of $\mathrm{NO}_{X}$ on road section No. 5 is $\sim 95 \%$

Fig. 6 Influence of the accumulated mileage on the emissions of passenger cars imported in 2000 and later

higher than that on road section No. 1. Accordingly, the average vehicle speed on road section No. 5 is $15 \mathrm{~km} / \mathrm{h}$, much lower than the speed on road section No. 1 $(62 \mathrm{~km} / \mathrm{h})$.

To better understand the relationship between emissions of the gasoline passenger cars and the driving conditions, the on-road emission test data were grouped into many 

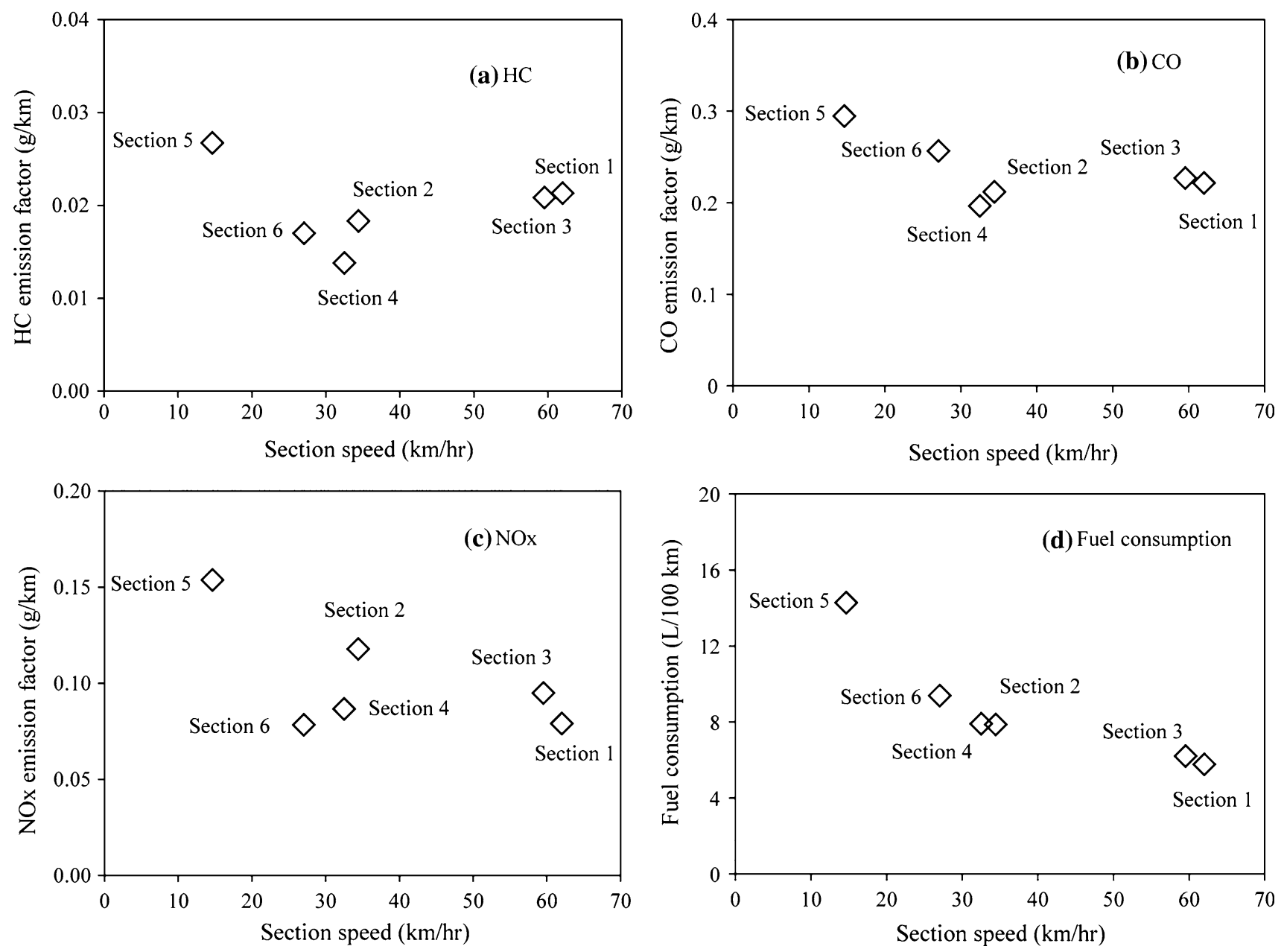

Fig. 7 Average fuel consumption and emission factors of the nine passenger cars registered after 2000 over the six road sections

micro-trips. The relative emission level of these micro-trips was calculated dividing the normalized baseline emission level of corresponding vehicle sample. Figure 8 presents the effect of average speed on the relative emission level of the micro-trips of all the 16 gasoline passenger cars tested. Average speed has significant impacts on the emission factors and fuel consumption of gasoline passenger cars in Macao. All the gasoline passenger vehicles have shown much worse performance in both fuel consumption and emissions when driven at low vehicle speed (usually due to high congestion). With SPSS $^{\mathrm{TM}}$, a statistical software, a mathematical fit is performed to determine the best curve estimation for three air pollutants and fuel consumption. Relative emission level of $\mathrm{HC}, \mathrm{CO}$ and $\mathrm{NO}_{X}$ are all best fitted to an inverse function. Relative level of fuel consumption is best fitted with power function. The results are also shown in Fig. 8. The relative emission levels of HC, $\mathrm{CO}$ and $\mathrm{NO}_{X}$ all show a tendency to increase when the average speed is below $20 \mathrm{~km} / \mathrm{h}$. Fuel consumption has shown a strong correlation with average speed. The correlation coefficient is higher than 0.95. Such a strong correlation between the fuel consumption/emissions of a vehicle and the road conditions indicates that a complete and precise emission inventory for on-road vehicles in Macao needs to be developed with input better reflecting the driving conditions.

We can use the regressed functions to estimate the potential effect of speed changes. The average speed of rush hours at the Macao Peninsula was $15 \mathrm{~km} / \mathrm{h}$ in 2010 (Transportation Bureau of Macao 2010). Compared to the average driving conditions $(34.3 \mathrm{~km} / \mathrm{h})$ during the on-road test in this study, the emission factors of $\mathrm{HC}, \mathrm{CO}$ and $\mathrm{NO}_{X}$ and fuel consumption of gasoline passenger cars will increase by $61,55,45$ and $90 \%$, respectively. If no further transportation management strategies are implemented in Macao, the average speed of rush hours on the Macao Peninsula will decrease from $15 \mathrm{~km} / \mathrm{h}$ in 2010 to $10 \mathrm{~km} / \mathrm{h}$ in 2015 (Transportation Bureau of Macao 2010). The emission factors of $\mathrm{HC}, \mathrm{CO}$ and $\mathrm{NO}_{X}$ and fuel consumption of gasoline passenger cars will further increase by 34,32 , 

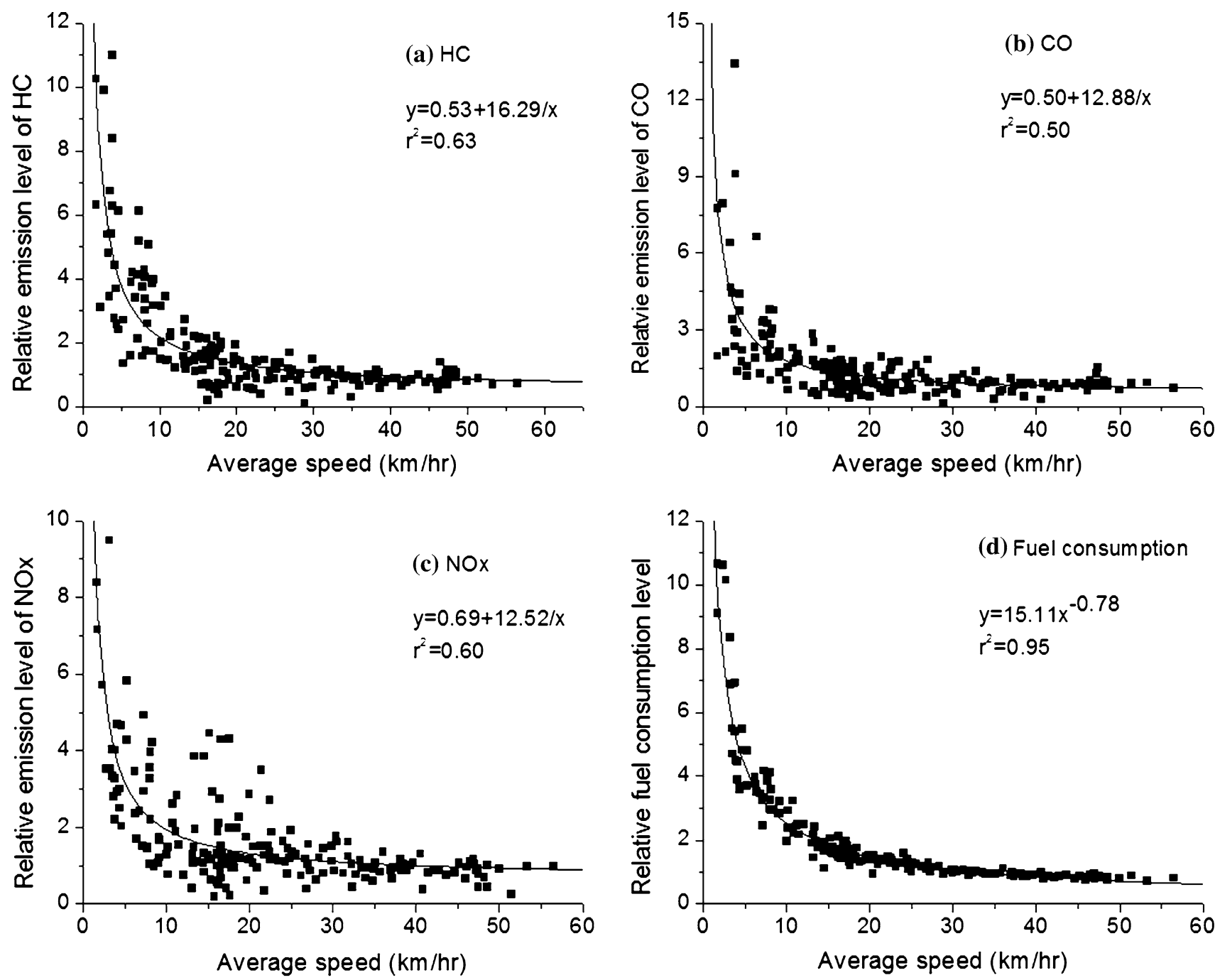

Fig. 8 Relative emissions and fuel consumption of the 16 gasoline passenger cars over all the micro-trips

27 and $37 \%$, respectively. Therefore, to reduce air pollutant emissions and save fuel in an urban area, traffic planning and travel demand management also need to be improved.

\section{Conclusion}

The on-road fuel efficiency and exhaust emission profiles of light-duty gasoline passenger cars in Macao are different than their counterparts in mainland China. Passenger cars with model year older than 2000 are much dirtier than those newer models. In terms of control of the total emissions of motor vehicles in Macao, the scrappage of older gasoline cars should be a priority. However, two low emitters have been identified among vehicles registered before 2000. They have $\mathrm{NO}_{X}$ emission level comparable to the vehicles registered after 2000. An effective emission inspection program with efficient test method and emission limits should be developed to screen them from other high emitters. The emissions of gasoline passenger cars are much better than diesel taxis of similar age in Macao. The emission levels of gasoline passenger cars newer than 2000 in Macao are close to Euro IV LDGVs in mainland China. The emission levels of $\mathrm{HC}$ and $\mathrm{NO}_{X}$ of passenger cars older than 2000 are close to Euro 0 LDGVs in mainland China, while their CO emission levels are close to Euro 1 LDGVs in mainland China.

We have identified some newer sampled vehicles with very high $\mathrm{CO}$ and $\mathrm{NO}_{X}$ emissions. An emission inspection program based on a loaded test method and reasonably stringent cut points is necessary for Macao to control imported and in-use vehicle emission levels. Cars to be scrapped could also be tested by the loaded test to assure 
they are high emitters. This may further gain support for the program from vehicle owners. Model year 2000 can be used as the cut line for setting in-use emission limits. As the age and mileage of vehicles newer than 2000 have shown no significant effect on the emissions, their limits currently do not need to be further classified.

Based on relative emission levels, a clear and similar pattern for gaseous pollutants and fuel consumption with driving conditions was identified. The emissions of $\mathrm{HC}$, $\mathrm{CO}$ and $\mathrm{NO}_{X}$ are best fitted to average speed with inverse functions. Fuel consumption is best fitted to average speed with a power function. Compared to the average driving conditions, the emission factors of $\mathrm{HC}, \mathrm{CO}$ and $\mathrm{NO}_{X}$ and fuel consumption of gasoline passenger cars during the rush hours will be increased by $61,55,45$ and $90 \%$, respectively. The condition will worsen by 2015 if no further transportation management strategies are implemented in Macao. To save energy and mitigate the $\mathrm{CO}_{2}$ emissions as well as other air pollutant emissions in the urban area, improved traffic planning and travel demand management are also necessary.

Acknowledgments This work was supported by the National High Technology Research and Development Program (863) of China (No. 2009AA06Z304), Macao Environmental Protection Bureau, the National Natural Science Foundation of China (No. 50908121) and the Environmental Public Welfare Project (No. 201209002). The authors are grateful to Macao Transportation Bureau for their support on real-world emission tests of gasoline passenger cars in Macao SAR. The authors also thank Mr. Chuck Freed, formerly of US EPA for his helpful advice to improve this paper. The contents of this paper are solely the responsibility of the authors and do not necessarily represent official views of the sponsors.

\section{References}

Administration of Quality Supervision, Inspection and Quarantine of the P. R.China (AQSIQ China) (2003) Measurement methods of fuel consumption for light-duty vehicles, GB/T 19233-2003. Beijing, China

André M (2004) The ARTEMIS European driving cycles for measuring car pollutant emissions. Sci Total Environ 334-335: $73-84$

Chan AT, So ESP, Samad SC (2001) Strategic guidelines for street canyon geometry to achieve sustainable street air quality. Atmos Environ 35(24):4089-4098

Chen C, Huang C, Jing Q, Wang H, Pan H, Li L, Zhao J, Dai Y, Huang H, Schipper L, Streets DG (2007) On-road emission characteristics of heavy-duty diesel vehicles in Shanghai. Atmos Environ 41(26):5334-5344

U.S. EPA (2001) Final Facility-Specific Speed Correction Factors. U.S. EPA, Washington DC (EPA-420-R-01-060)

Gkatzoflias D, Kouridis C, Ntziachristos L, Ntziachristos L, Samaras Z (2007) COPERT 4 computer programmer to calculate emissions from road transport user manual (version 5.0). Copenhagen: European Environment Agency

Hao J, Fu L, He K, Wu Y (2000) Urban vehicular pollution control. China Environmental Science Press, Beijing
Hao J, Wu Y, Fu L, He D, He K (2001) Source contributions to ambient concentrations of $\mathrm{CO}$ and $\mathrm{NO}_{\mathrm{X}}$ in the urban area of Beijing. J Environ Sci Health 36(2):215-228

Hu J, Hao J, Fu L, Wu Y, Wang Z, Tang U (2004) Study on on-board measurements and modeling of vehicular emissions. Environ Sci 25(3):19-25

Hu J, Wu Y, Wang Z, Li Z, Zhou Y, Wang H, Bao X, Hao J (2012) Real-world fuel efficiency and exhaust emissions of light-duty diesel vehicles and their correlation with road conditions. J Environ Sci 24(5):865-874

Huo H, Yao Z, Zhang Y, Shen X, Zhang Q, Ding Y, He K (2012) On-board measurements of emissions from light-duty gasoline vehicles in three mega-cities of China. Atmos Environ 49: 371-377

Kho FWL, Law PL, Ibrahim SH, Sentian J (2007) Carbon monoxide levels along roadway. Int J Environ Sci Technol 4(1):27-34

Koupal J, Nam E, Giannelli B (2004) The MOVES approach to modal emission modeling. 14th CRC On-road Vehicle Emissions Workshop, San Diego

Li Z, Hu J, Bao X, Pu Y, Zhang G (2009) Gaseous pollutant emission of China 3 heavy-duty diesel vehicles under real-world driving conditions. Re Environ Sci 22(12):1389-1394 (in Chinese)

Macao Statistics and Census Service (2012) Transport and communications statistics. Available at: http://www.dsec.gov.mo/get Attachment/33036a05-720d-4604-80f4-b6b5a0a068c1/C_ETC_ FR_2011_M12.aspx Accessed 1 Feb 2012

Malakootian M, Yaghmaeian K (2004) Investigation of carbon monoxide in heavy traffic intersections of municipal districts. Int J Environ Sci Technol 1(3):227-231

Ministry of Environmental Protection, China (MEP China) (2010) First national census of pollution sources. Available at http:// www.mep.gov.cn/gzfw/xzzx/wdxz/201002/P0201002255360251 77826.pdf. Accessed 3 Feb 2012

Ministry of Environmental Protection, China (MEP China) (2011) China vehicle emission control annual report. Available at http:// www.mep.gov.cn/gkml/hbb/qt/201112/W020120412491271557 209.pdf. Accessed 3 Feb 2012

Poppel M, Lenaers G (2005) Real life evaluation of the emission reduction potential of a city bus retrofitted with a continuous regenerating trap. Atmos Environ 39(13):2451-2457

Tang UW, Wang Z (2006) Determining gaseous emission factors and driver's particle exposures during traffic congestion by vehicle following measurement techniques. J Air Waste Manag Assoc 56(11):1532-1539

Tang UW, Wang Z (2007) Influences of urban forms on trafficinduced noise and air pollution: results from a modeling system. Environ Model Softw 22:1750-1764

Transportation Bureau of Macao (2010) Consultation report on the road transportation policy planning of Macao (2010-2020). Available at: http://www.dsat.gov.mo/ptt/sc/doc.pdf Accessed 23 March 2012

Unal A, Frey HC, Rouphail NM (2004) Quantification of highway vehicle emissions hot spots based upon on-board measurements. J Air Waste Manag Assoc 54(2):130-140

Westerdahl D, Wang X, Pan X, Zhang KM (2009) Characterization of on-road vehicle emission factors and microenvironmental air quality in Beijing, China. Atmos Environ 43(3): 697-705

Wu Y, Hao J, Fu L, Wang Z, Tang UW (2002) Vertical and horizontal profile of airborne particulate matter near major roads in Macao, China. Atmos Environ 36(31):4907-4918

Wu Y, Wang R, Zhou Y, Lin BH, Fu L, He K, Hao J (2011) On-road vehicle emission control in Beijing: past, present and future. Environ Sci Technol 45(1):147-153

Yang L, Wu Y, Davis JM, Hao J (2011) Estimating the effects of meteorology on PM 2.5 reduction during the 2008 Summer 
Olympic Games in Beijing, China. Front Environ Sci Eng China 5(3):331-341

Yao Z, Wang Q, He K, Huo H, Ma Y, Zhang Q (2007) Characteristics of real-world vehicular emissions in Chinese cities. J Air Waste Manag Assoc 57(11):1379-1386
Zhou Y, Wu Y, Yang L, Fu L, He K, Wang S, Hao J, Chen J, Li C (2010) The impact of transportation control measures on emission reductions during the 2008 Olympic Games in Beijing, China. Atmos Environ 44(3):285-293 